\title{
EVALUATION OF PATIENTS WITH SCHISTOSOMAL PORTAL HYPERTENSION TREATED IN A TERTIARY HOSPITAL
}

\section{Perfil dos pacientes com Esquistossomose Mansoni tratados em hospital terciário}

\author{
Fábio Ferrari MAKDISSI, Paulo HERMAN, Renata Potonyacz COLANERI, \\ Barbara dos Santos NUNES, Vincenzo PUGLIESE, Roberto de CLEVA, William A. SAAD, \\ Luiz Augusto Carneiro D`ALBUQUERQUE, Ivan CECCONELLO
}

ABCDDV/675

Makdissi FF, Herman P, Colaneri RP, Nunes BS, Pugliese V, Cleva R, Saad WA, D’albuquerque LAC, Cecconello I. Evaluation of patients with schistosomal portal hypertension treated in a tertiary hospital. ABCD Arq Bras Cir Dig 2009;22(4):212-5

ABSTRACT - Background - Schistosomiasis is an important public health issue in more than 70 countries around the world. About 600 million people are at risk to acquire the parasite and there are 200 million infected worldwide. Aim - To evaluate the characteristics of schistosomal portal hypertension individuals who underwent previous esophageal varices bleeding treated in a tertiary hospital. Methods - The records of 155 patients were evaluated and clinical, laboratorial, endoscopic, epidemiological features and hemorrhagic event severity were analyzed to individualize this population. Results - Mean age was 37.2 years and no clinical signs of hepatic failure were observed. Serum laboratory tests to evaluate liver function were normal or slightly alter. Anemia was present in $70 \%$, leucopenia in $75 \%$ and thrombocytopenia in $86 \%$ of the patients. At endoscopic evaluation varices were classified as grade III and IV in $91.3 \%$; red spots were observed in $40.3 \%$ and congestive gastropathy in $13.6 \%$. Patients presented a mean of 2.8 previous episodes of variceal hemorrhage and, in $75 \%$ with hemodynamic instability. Conclusions - Patients with schistosomal portal hypertension and history of upper digestive bleeding from esophageal varices are young individuals, without either clinical or laboratorial evidence of liver dysfunction, that present high morbidity due to the severity of the acute event of bleeding.

HEADINGS - Schistosoma mansoni. Portal hypertension. Esophageal varices. Upper gastrointestinal bleeding.

\section{INTRODUCTION}

Schistosomiasis is an important public health issue in more than 70 countries around the world. About 600 million people are at risk to acquire the parasite and there are 200 million people infected worldwide ${ }^{18}$. Although this is an evitable and curable disease, the costs for the control are very high and progress on treatment is delayed by economical issues of undeveloped countries. In Brazil the parasitosis is caused by Schistosoma mansoni and in 1990 it was estimated that 30 million people were exposed to the infection and about three to four million infected ${ }^{2,18}$.

The major public health impact is caused by chronic infection leading to intestinal, liver and spleen involvement. The hepatosplenic form of the disease is the most relevant cause of morbidity and mortality in Schistosoma mansoni infection. This presentation occurs in up to $10 \%$ of the infected patients and is characterized by periportal liver fibrosis and consequently portal hypertension, leading to the formation of collateral circulation and risk of bleeding due to esophageal varices rupture ${ }^{1}$.

From the Department of Gastroenterology - University of São Paulo Medical School, São Paulo, SP, Brazil

Correspondence: Pa ulo Herman, e-mail : pherman@uol.com.br
Upper digestive bleeding from esophageal varices may occur in approximately $60 \%$ of the patients ${ }^{4,7,8,10}$. In Brazil, the annual mortality caused by schistosomiasis was estimated in 0.3 per 100.000 inhabitants and in the rural population the disease represents an important cause of death ${ }^{2,9}$.

The majority of individuals affected by the disease are young, economically active and present a normal liver function. Hepatic failure is rare and, when present, is related to other concomitant diseases such as viral hepatitis or chronic alcohol abuse. Indeed, bleeding from esophageal varices rupture is an important cause of mortality in these patients being the most relevant disease complication ${ }^{7,10,15,17}$.

The objective of this study was to analyze clinical, epidemiological, laboratorial and endoscopic features of the population with schistosomal portal hypertension and history of upper digestive bleeding due to esophageal varices rupture treated in a tertiary university hospital.

\section{METHODS}

One hundred and fifty five patients with hepatosplenic form of schistosomiasis and history of upper digestive bleeding from esophageal varices rupture that were submitted to surgical treatment by azigo-portal discon- 
nection and splenectomy were studied between March 1989 and April 2000.

Diagnosis was based in epidemiologic, clinic and laboratorial data and confirmed by histologic evaluation.

Patients who had viral hepatitis or chronic alcohol abuse or those with histologic evidence of another hepatopathy were excluded from this study.

All patients had been previously submitted to the parasitosis treatment with oral oxamnique or praziquantel. Patients were evaluated on clinic and nutritional status, and the body mass index was calculated (body mass index between $20-25 \mathrm{Kg} / \mathrm{m}^{2}$ was considered as normal). Clinical signs of liver failure as the presence of ascitis, jaundice, liver encephalopathy, spiders and palmar eritema were evaluated.

Bleeding episodes due to esophageal varices rupture were characterized by its frequency, number, presence or not of hemodinamic repercussion and the need of any therapeutic measure.

The following laboratorial tests were evaluated: complete blood account, serum AST, ALT, alkaline phosfatase and gammaglutamil transpeptidase, bilirubins, total protein and albumin and prothrombin activity and RNI.

All patients underwent upper digestive endoscopy to confirm the presence of esophageal varices that were evaluated by its number, location, caliber and presence of red spots. The occurrence of congestive gastropathy was analyzed as well. After endoscopy patients were classified according to Paquet's classification (Figure 1).

\begin{tabular}{|l|l|}
\hline Grade 0 & Absence of esophageal varices \\
\hline Grade I & $\begin{array}{l}\text { Microcapillars located on esophagogastric transition or distal } \\
\text { esophagus }\end{array}$ \\
\hline Grade II & 1 or 2 small varices located on distal esophagus \\
\hline Grade III & Medium varices \\
\hline Grade IV & Large varices in any part of the esophagus \\
\hline
\end{tabular}

FIGURE 1 - Endoscopic classification of esophageal varices according to Paquet ${ }^{11}$

All patients were submitted to abdominal ultrasound for liver, spleen and portal system evaluation.

\section{RESULTS}

There were 93 male $(60 \%)$ and $62(40 \%)$ female patients with a mean age of 37.2 years (range: 15 to 75 years). The majority of patients $(89.7 \%$ ) were migrants from the states of Bahia, Minas Gerais and Pernambuco (Table 1).

TABLE 1 - Distribution of patients according to their state origin

\begin{tabular}{lll}
\hline Stage of origin & Number of patients & $\mathbf{\%}$ \\
\hline Bahia & 61 & 39,4 \\
Minas Gerais & 46 & 29,7 \\
Pernambuco & 32 & 20,6 \\
Alagoas & 5 & 3,2 \\
Sergipe & 4 & 2,6 \\
Other & 7 & 4,5 \\
\hline Total & $\mathbf{1 5 5}$ & $\mathbf{1 0 0}$ \\
\hline
\end{tabular}

All patients were in good clinical conditions with no signs of liver failure. The body mass index varied from 17 to 30 (mean: $23 \mathrm{Kg} / \mathrm{m}^{2}$ ). The spleen was palpable in $135(87 \%)$ patients.

The number of bleeding episodes varied from one to 15 , mean of 2.8 and median of two episodes per patient. Among 108 patients who had more than one bleeding episode, the interval between the first and the second hemorrhagic episode was less than a year in 58.6\%.

Upper digestive bleeding leaded to hemodynamic instability in $75.5 \%$ of the patients and blood transfusion was necessary in 112 (74.2\%). Transfusion volume varied from 1 to 20 blood packs with a mean of three units per patient.

Thirteen patients $(8.6 \%)$ needed the insertion of the Sengstaken-Blakemore balloon in order to stop bleeding while 83 patients $(54.6 \%)$ have received some kind of endoscopic treatment during the bleeding episode or as secondary prophylaxis. In 69 patients $(45.4 \%)$ bleeding stopped spontaneously.

One hundred and six patients $(70 \%)$ had hemoglobin below $12 \mathrm{~g} / \mathrm{dL}$, mean of $10.6 \mathrm{~g} / \mathrm{dL} ; 114(75 \%)$ leucocytes number below 4000 per $\mathrm{mm}^{3}$, mean of 3390 leucocytes/ mm3; 129 (86.5\%) platelets count below 140,000 per $\mathrm{mm} 3$, mean of 87000 per $\mathrm{mm}^{3}$.

One hundred and twenty six patients $(84.5 \%)$ presented serum albumin higher than $3.5 \mathrm{~g} / \mathrm{dL}$, mean of 4.2 $\mathrm{g} / \mathrm{dL}$ and $111(85 \%)$ had total serum bilirrubin levels up to $1,5 \mathrm{mg} / \mathrm{dL}$, mean of $1,08 \mathrm{mg} / \mathrm{dL}$. Patients with total bilirrubin levels higher than $1.5 \mathrm{mg} / \mathrm{dL}$, had this increase due to indirect billirubins. Ninety seven patients had prothrombin activity higher than $60 \%$ (74\%), mean of $68 \%$.

Eighty one patients $(52.6 \%)$ had esophageal-gastric varices classified as grade IV, $60(39 \%)$ as grade III, nine $(5.8 \%)$ as grade II, two (1.3\%) as grade I and two (1.3 $\%)$ as grade 0 . Twenty one patients $(13.6 \%)$ presented congestive gastropathy and $62(40.3 \%)$ signs of red spots.

Ultrasound evaluation showed suggestive signs of chronic liver disease with periportal fibrosis and portal hypertension with splenomegaly and collateral circulation in all patients.

\section{DISCUSSION}

In Brazil, mansonic schistosomiasis is an endemic disease, and according to the present study,was noticed that most of the patients $(90.4 \%)$ were migrants from the states of Bahia, Minas Gerais and Pernambuco.

Schistosomal infection can be treated with drugs such as praziquantel or oxamniquine, however in the advanced form of the disease, periportal liver fibrosis, collateral circulation and portal hypertension are irreversible ${ }^{17,19}$. When the hepatosplenic form of the disease is established the use of these drugs are not efficient to avoid bleeding from esophageal varices rupture ${ }^{16}$.

Upper digestive bleeding is the most feared complication in patients with schistosomiasis and is usually the first manifestation of the disease. The selected group in 
this study was composed by young individuals with mean age of 37.2 years old and all patients were in good clinical and nutritional conditions. Moreover no clinical or laboratory signs of liver failure were observed, reinforcing that patients with schistosomiasis have a preserved liver function. The only finding at physical examination is an enlarged spleen, another typical characteristic of the disease ${ }^{17}$.

Laboratorial evaluation showed that most patients had anemia, thrombocytopenia and leucopenia. Anemia was probably related to previous digestive bleeding episodes, and in some patients, carencial anemia, due to low socioeconomic conditions. Thrombocytopenia as well as leuchopenia observed respectively in $86.5 \%$ and $75 \%$ of the patients may be due to the hypersplenism, a typical characteristic of hepatosplenic schistosomiasis, where platelets and leukocytes are kidnapped by the huge spleen $^{15}$. Liver function laboratory tests such as albumin, bilirubins and prothrombin activity were within normal limits or slightly altered.

The presence of red spots and large esophageal varices are known as risk factors for varices rupture and bleeding. In our study, endoscopic data showed that $91.6 \%$ of patients had medium and large varices and $40.3 \%$ had red spots signs, showing the high risk of bleeding in this population.

Patients had a mean of 2.8 upper digestive bleeding episodes due to varices rupture before hospital admittance for surgical treatment and approximately $70 \%$ had more than one bleeding episode, being the second one in less than one year from the first episode in $53.7 \%$ of the patients. Hemodynamic instability was observed in 75.5 $\%$ and blood transfusion was necessary in $74.2 \%$ of the cases. The bleeding caused by esophageal varices rupture is the most relevant disease complication, leading to high rates of morbidity and mortality $3,4,8,10,16,17$.

Considering the severity of previous bleeding episodes and the high recurrence rate in a short interval of time, moreover the high incidence of large esophageal varices and the presence of red spots, treatment should be aggressive to avoid bleeding recurrence. The majority of groups that lead with the disease employ esophagogastric devascularization (azigo-portal disconnection) and splenectomy as the preferred surgical treatment ${ }^{5,6,8,11,14}$.

\section{CONCLUSIONS}

Patients with schistosomal portal hypertension and history of upper digestive bleeding from esophageal varices are young individuals, without either clinical or laboratorial evidence of liver dysfunction, that present high morbidity due to the severity of the acute event of bleeding.

Makdissi FF, Herman P, Colaneri RP, Nunes BS, Pugliese V, Cleva R, Saad WA, D’albuquerque LAC, Cecconello I. Perfil dos pacientes com Esquistossomose Mansoni tratados em hospital terciário. ABCD Arq Bras Cir Dig 2009;22(4):212-5

RESUMO - Racional - Esquistossomose é importante doença na saúde pública envolvendo mais de 70 países. Cerca de 600 milhões de pessoas estão em áreas de risco para adquirir a doença e em torno de 200 milhões estão por ela infectados. Objetivo - Avaliar as características da hipertensão porta esquistossomótica em indivíduos que se submeteram previamente a tratamento de varizes esofágicas hemorrágicas em hospital terciário. Métodos - Os prontuários de 155 pacientes foram avaliados analisando-se aspectos clínicos, laboratoriais, endoscópicos, epidemiológicos e intensidade de eventos hemorrágicos. Resultados - A idade média foi de 37.2 anos e não havia sinais clínicos de insuficiência hepática. Análises séricas para avaliação da função hepática foram normais ou levemente alteradas. Anemia estava presente em $70 \%$, leucopenia em $75 \%$ e trombocitopenia em $86 \%$. Na endoscopia as varizes foram classificadas em graus III e V em $91.3 \%$; red spots foram vistos em $40.3 \%$ e gastropatia congestiva em $13.6 \%$. Os pacientes apresentaram média de 2.8 prévios episódios de hemorragia por varizes e em $75 \%$ havia instabilidade hemodinâmica. Conclusões - Pacientes com hipertensão porta esquistossomótica e histórico de sangramento digestivo alto por varizes esofágicas são jovens, sem evidências laboratoriais de alteração hepática importante e apresentam alta morbidade, devido à severidade do evento hemorrágico.

DESCRITORES - Schistosoma mansoni. Hipertensão portal. Varizes esofágicas. Hemorragia digestiva.

\section{REFERÊNCIAS}

1. Bina JC, Prata A. Esquistossomose na área hiperendêmica de Taquarandi. Infecção pelo Schistosoma mansoni e formas graves, Revista da. Sociedade. Brasileira de. Medicina Tropical. 36:211-216, 2003.

2. Brasil. Ministério da Saúde-Secretaria de Vigilância em Saúde. Vigilância epidemiológica: Programa de Controle da Esquistossomose-PCE. Disponível em: http://tabnet.datasus.gov.br/cgi/deftohtm.exe?sinan/pce/cnv/pce.def

3. Coutinho EM, Abath FGC, Barbosa CS, Domingues ALC, Melo MCV, Montenegro SML, Lucena MAF, Romani SAM, Souza WV, Coutinho AD. Factors involved in Schistosoma mansoni infection in rural areas of Northeast Brazil. Memórias do Instituto Oswald Cruz. 92:707-15, 1997.

4. Cury AA. Hepato-splenic form of the schistosomiasis: contributions to the natural history. Revista do Colégio Brasileiro de Cirurgia. 16:117-21, 1989.
5. De Capua Junior A, Szutan LA. Desconexão ázigo-portal e esplenectomia mais escleroterapia no tratamento da hipertensão portal. Clin Bras Cir 2:231-42, 1991.

6. De Cleva R, Herman P, D'Albuquerque LAC, Pugliese V, Santarem OL, Saad WA. Pre and postoperative systemic hemodynamic evaluation in patients subjected toesophagogastric devascularization plus splenectomy and distal splenorenal shunt: a comparative study in schistosomal portal hypertension. World J Gastroenterol 13:5471-5, 2007.

7. Ezzat FA, Abu-Elmagd KM, Aly IY, Aly MA, Fathy OM, el-Barbary MH, Bahgat OO, Salam AA, Kutner MH. Distal splenorenal shunt for management of variceal bleeding in pacients with schistosomal hepatic fibrosis. Annals of Surgery. 204:566-74, 1986. 
8. Ferraz AAB, Lopes EPA, Barros FMR, Sette MJA, Arruda SMB, Ferraz EM. Esplenectomia com ligadura da veia gástrica esquerda e desvascularização da grande curvatura do estômago no tratamento da esquistossomose hepatoesplênica. É necessária a escleroterapia endoscópica pós-operatória? Arquivos de Gastroenterologia. 38:84-8, 2001.

9. Ferreira ILM, Tabosa, TSP. Mortalidade por esquistossomose no Brasil: 19802003. Rev Patol Trop 36:67-74, 2007.

10. Kelner S. Avaliação crítica da cirurgia na hipertensão portal esquistossomótica. Memórias do Instituto Oswald Cruz. 87(IV):357-368, 1992.

11. Makdissi FF, Herman P, Machado MAC, Pugliese V, D'Albuquerque LAC, Saad WA, Cecconello I. Trombose de veia porta após desconexão ázigo-portal e esplenectomia em pacientes esquistossomóticos: qual a real importância?Arq Gastroenterol 46:50-56, 2009.

12. Paquet KJ. Prophylactic endoscopic sclerosing treatment of the esophageal wall in varices - a prospective controlled randomized trial. Endoscopy. 14:4-5, 1982.

13. Petroianu A, Oliveira AE, Alberti LR. Hyperspenism in schistosomotic portal hypertension. Arch Med Res 36:496-501, 2005.
14. Raia S, da Silva LC, Gayotto LC, Forster SC, Fukushima J, Strauss E. Portal hypertension in schistosomiasis: a lon-term follow-up of a randomized trial comparing three types of surgery. Hepatology. 20:398-403, 1994.

15. Raia S, Mies S, Alfieri Júnior F. Portal hypertension in mansonic schistosomiasis. World Journal of Surgery. 15:176-87, 1991.

16. Richter J. The impact of chemotherapy on morbidity due to schistosomiasis. A very comprehensive review of the impact of chemotherapy on schistosomiasis morbidity with several good tables providing a useful overview of the large number of studies using different treatment regimes and methods of morbidity assessment. Acta Trop 2003; 86: 161-183

17. Silva LC, Carrilho FJ. Hepatosplenic schistosomiasis. Pathophysiology and treatment. Gastroenterology Clinics of North America. 1992;21:163-77.

18. WHO. The control of schistosomiasis. Who Techinical Report Series no 830. Geneva. World Health Organization, 86, 1993.

19. Zeitune JMR, Ramos SR, Sugmyama LCY, Corte AA. Tratamento medicamentoso da esquistossomose mansoni. Arq Gastroenterol 1980;17:88-95.

Fonte de financiamento: não há

Conflito de interesse: não há Recebido para publicação:30/09/2009 Aceito para publicação: 04/11/2009 